\title{
Visual Cultural Practice and the Politics of Aesthetic Discourse Don Krug
}

This paper argues that the politics of aesthetic discourse is interconnected and active within and between social structures in the micro and macro environment. They are formed in response to socially interested agency and culture, over conflict of interests, and across erected lines of official art and non official art "making" (Jones, 1975). Multiple views form and are concerned with both a "designation of difference" and "distinctions of taste". Aesthetic discourses circulate and are centered around these real life problems and the legitimate status of certain forms of visual cultural products and practices and how they are used and consumed in elaborate capitalistic societies. The problem identified, recognized and that needs to be articulated and resolved concerns how and why people in privileged positions in society produce and reproduce, circulate and distribute discourses that "dehumanize" particular groups of people or makers of art, their cultural practices and art forms (Gasset, 1925). Folk, primitive, naive, grassroot and more recently visionary, intuitive and outsider are just a few examples of the ever expanding list that categorizes individual makers as culturally distinct groups of people. The paper briefly overviews the problem, and looks at visual cultural practice and the politics of aesthetic discourse for how they operate in both the micro and macro environments of society.

Oral life histories as written narratives are a powerful way "to see" connections when studying visual culture and the practices of people who "make things" in their actual lived experiences and immediate home environment (hooks, 1992; Gee, 1991; Irwin, 1982; Jones, 1975; Sherzer, 1983; Tannen, 1984; Zurmuehlen, 1990). The research from which this paper is generated is grounded in the "story events" told by Wisconsin self taught vernacular artists (Georges, 1969). Vernacular is a descriptive term that recognizes the place from which self-taught artists speak. Lippard (1991) suggests, "vernacular gives people a way to speak for themselves, across the moat [the conflict of interests] that protects the high-art world [official art] from knowing what 'the people' really think and seen (p. 78). It signifies that people are culturally productive in the practices of their lives no matter where their home is located. Willis (1990) suggests, "We are all cultural producers in some way and of some kind in our everyday lives. It is still often denied or made invisible in many of our official attitudes and practices, in our lives and communications" (p. 128). Alternative methods to traditional naturalistic research are necessary because the experiences of people living within complex societies are too often times silenced or bound by a set of assumptions about the world that generates the theory of the research. 
The paper is divided into two sections. The first section examines the cultural practices of a self-taught vernacular Wisconsin artist within the concept of the everyday. Cultural practices in the micro and macro environment are mediated (talked about), internalized (thought about), and encountered (directly experienced), in a constant process carried out under particular material and semiotic conditions. They are shaped, contained and mutually informed by the environmental situation and its textuality. The paper investigates how the satisfaction one maker receives from the act of making is not determined in the completion of the end product produced. Instead, satisfaction is generated in the process as a form of discursive relevance from "making" the product. The second and final section discusses how aesthetic discourse is strategically connected to particular sites and organizations. Briefly considered are the popular periodical press and art education's selective tradition. It is in the micro environment that I begin the interpretive process "grounded" in the oral life histories of the makers, their home environment, and practices.

\section{Cultural Practice in the Micro Environment}

In March of 1992, I visited a Wisconsin self-taught vernacular artist. As I entered his service station, I noticed a newspaper clipping proudly displayed on the entrance wall. Over the years it had become torn and yellowed from the sunlight streaming through a large picture window. The front page headline read, Steel Dinosaur Protects Muscoda's' South Side. The article and accompanying photograph featured Ellis Nelson. Published on the first Thursday in February of 1985, in The Progressive, a small weekly paper in Muscoda, the photo shows Ellis standing behind a 6 foot high by 10 foot long yellow polka dot creature that he made in his spare time. It has bluish gray skin, and a bright blue eye, made from one of his son's left over Easter eggs, "the plastic kind that pops apart," he said. The article asks, "What do you do when the temperature gets way below zero and you have time to pass?" For Ellis Nelson, the answer was obvious. He combines and transforms the materials around him, l.e. sheet metal, pleces of old screen, spray paint, and other odds and ends. He selects, combines and reprocesses the resources available in his everyday life, "maklng do" with what he has, working with the skills he's acquired and developed over the years as a service mechanic, a gunsmith, and as an electrician (de Certeau, 1984). Ellis has always enjoyed "making" things. Even as a young child, he explains,

"I had an old car battery (he was about eight at the time) one time and $\mathrm{um}, \mathrm{I}$ found an old generator, off of a car and something and I put the ... I put a propeller on it out in the wind and it would charge this battery up for, it would charge the battery up for me, so therefore, then I run the wires into the house, into my bedroom and I would take flashlight batteries ... flashlight bulbs, and I had those on the walls all over it and I had light in my bedroom". 
A bricoleur, Ellis is a collector of the ordinary and banal items of used, unused and discarded material. (de Certeau, 1984). He poaches on the resources of a market economy, collecting the items and storing them in his shop. The collected materials create an arrangement, a "style" of space in an environment, a bricolage, that come from a variety of sources, i.e. the local salvage yard, businesses, and friends. Ellis takes these items and transforms them into extraordinary "wire and metal forms". He explained, "I wasn't busy on a Saturday, doin' much. So I told my son, I said "Say! I've gotta, l'd like to build a . . . sign for my shop in the shape of a Sinclair dinosaur, I think". As we sat talking more than seven years after he had made his first construction, one could tell he had told this story many times before.

He continued, "It was a great big piece of metal. And I had fun drawing the Sinclair dinosaur on it". There was a sense of extreme pleasure and relevance conveyed, as we talked about his initial experience, not only in the words he selected to describe the process, but also in the intonation or the way he spoke, the use and accent of the words, made his extreme satisfaction in the practice of this act explicit. His great satisfaction is derived from the act of "making". The pleasure comes from the process that is relevant because it is derived from an interest he has in mechanical things. He said. "But I was never interested in school . . . school was not my thing at all, I was not interested ... um in um school . . I was only interested in mechanical and electrical things, is what I was interested in". The skills he acquired over the years, provide a "density of experiences" that work to produce the satisfaction and relevance in the process of "making" the metal and wire forms (Fiske, 1991b).

The pleasure and relevance he receives, are from the sense he makes from his own social life and social condition out of daily resources. It's not the sense that is made for him, or imposed on him, according to the needs of a social order or according to a dominant ideology. Therefore, it's not a source of experience, or identity, that a dominant social order necessarily wants, or can fit neatly into its organized structure of difference. Relevance is not predictable, but shitting, and is produced and becomes active in the details of the moment (Fiske, 1989). Ellis's story is not unusual. It is one example of many, about individuals who have found the practice of symbolic production, the cultural production of visual representation, to be an important part of their everyday lives. People are able to draw lines of pertinence between their cultural lives and their material or social lives. They choose and act to engage in certain aspects of their cultural lives, based on the pleasure, relevance and meanings produced. It is a form of discursive practice, a type of relevance generated out of the uses of resources from which one produces meanings. It is concerned with the process of producing meaning and pleasure more than it is with the meanings and pleasures that are actually produced.

People produce a "density of experiences", practices and objects that have contextually specific motivations and are of social importance in their lives. Discursive relevance produces a direct relationship of identity which 
can affect the internal and external behavior of individuals. The person's space and habitus are constructed by these internal and external forces. The conjunctural relation of the practices and structure operate in a mutually determining systemic process (Bourdieu, 1984). Determination is used here, as one dimension which "resolves or completes a process, it does not prospectively control or predict it" (Williams, 1976). Therefore, a tactic used by people in everyday life against the strategies of dominant culture is the construction of a bottom up density. Fiske (1991b) writes, "these practices and objects are not empty signifiers, they are not just a shiny surface, despite the shininess of their surfaces. They are deeply significant and firmly anchored in their user's way of life" (p. 169). Thus, on a political level, in the practice of everyday life, how beautiful an object is, or how it is appreciated becomes a secondary consideration to the process of the makers' actual use of things and its meanings, values, relevance and pleasure toward a particular way of living.

\section{Cultural Practice and the Macro Environment}

In the United States, 'distinctions of taste' over self taught making and 'authentic' institutionally trained artistic practices is well entrenched in society's notion of "what art is". However, most recently, a 'new aesthetic' connected to contemporary folk art has emerged that categorizes some makers as "outsiders". Michael D. Hall (1991) attributes the formation of a new aesthetic discourse to an American fascination for collecting the objects and things associated with people in everyday life, i.e. weather vanes, 'folk' portraits, that are "home grown". He refers to this behavioral fetishness as "domestic otherness" (p. 19) and points out that some of the first people to 'officially' (recorded) collect folk art objects were the actual artists themselves at Ogonquit colony (Rumford, 1980). It wasn't long, however, until dealers, museum and gallery directors followed suit and a show was coordinated in 1924 at the Whitney Studio Club exhibiting some forty-five objects. Ten years later, in 1934, another exhibit took place at the Museum of Modern Art. It was this show that established the 'place' of Folk art and/or 'domestic outsider' art in institutions of the macro environment. Folk and outsider art were identified, recognized, and it wasn't long until aesthetic discourse started to be circulated and distributed by art critics, gallery owners and museum curators. Dominant culture was wrapped up in "folk art fever" and was eager to collect and accumulate the new found wealth of the maker who made things outside the mainstream (Nach, 1991, p. 22).

Certain forms of cultural practice are accepted and incorporated into the "art world" as legitimate kinds of artistic production. Others are rejected, opposed and contested more regularly. The popular periodical press has been instrumental in circulating and distributing the new and 'discovered' people and their 'cultural practices'. It has had a profound impact on shaping people's common sense perceptions, their attitudes, beliefs, and dispositions. Collectors, dealers and museum directors, and interested patrons rely on the publications, magazines and newsletters for informational insight. In the

Working Papers in Art Education 1992 
process periodicals distribute, through discursive practices and aesthetic discourses, powerful definitions, images and biographies, to draw comparisons, either through purposeful analysis or accidental juxtaposition. They influence the art market, educational institutions and in the process shape our sense of social and cultural difference with regards to the makers' cultural practice.

In 1972 an English art historian, Roger Cardinal (1972), discussed in his book, Outsider Art, that the visual cultural practices of the self taught maker were not distinctly different from other forms of artistic practice he had studied. Nevertheless, he asserts, the work didn't seem to have anything to do with folk art, because it wasn't passed on or down in a regional, ethnic, religious, or occupational tradition. It wasn't fine art because it wasn't learned in an academic setting, and it wasn't commercial because it wasn't made to sell. Cardinal (1972) wrote, "the 'alternative' art to which the present book is addressed is to be sought not in cultures different from our own, since these do not break away from cultural norms and set figurations, but in true artistic heresies within the boundaries of our immediate system" (p. 39) (Cardinal's italics). Cardinal's book was instrumental naming the other as "outsider," even though the term outsider is rarely used in the text.

So how does the politics of aesthetic discourse work to form our common sense perceptions of a maker's cultural practices? The politics of aesthetic discourse is connected to the contention put forth by Weitz (1959) that, "art . . . is an open concept" (p. 152). 'Art' is by it very nature indefinable. Thus, art or symbolic cultural production is vulnerable for use by groups with special Interests to make it have different meanings, in particular ways. What art means in any one context can be understood in the social relations of its use, its conditions of consumption and production. However, cultural production and practices are not homogeneous concepts, well ordered into formalistic categories based on aesthetic conventions or technocratic rationale. Political and cultural struggles over meanings and value occur and need to be analyzed.

The politics of aesthetic discourse is a struggle over meaning(s) and can be analyzed along at least two dimensions. The first dimension is the struggle over how to make cultural practices mean differently. For example, in art education an alternative everyday contextual or socio cultural approach sees art as having multiple meanings connected to social and political forces. Symbolic production and its associated practices are perceived as contextually oriented. On the other hand, a formalistic conservative aesthetic approach sees art as having a universal or transcendent meaning. It is perceived as relatively autonomous and non-contextually specific. From this perspective, art is definable. Its meaning is acquired through an aesthetic disposition one obtains by adopting a particular attitude. In the second social and political dimension, the struggle is over what meanings art will mean, and in what particular circumstances; what meanings are actually promoted, and in what particular set of "social relations". Broadly speaking, on a social and 
political level, the divisions between particular points of view, connected to aesthetic discourse and a 'designation of difference', are analyzable from both a conservative and a socio-contextual perspective. The crucial difference between these two points of view is that while conservative theories recognize differences between 'high brow' and 'low brow', they tend not to recognize the 'validity of conflict' across that difference. Differences from a conservative perspective are characterized in terms of 'quality'.

Preferred tastes are based on categories of quality. The quality of cultural practices and production is measured according to the critical appraisal by experts based on aesthetic universal standards of taste, and the symbolic products' ability to survive the test of time. (Hamblen, 1990; Broudy, $1972 ;$ Smlth, 1967, 1986). What is critically absent in the assessment process by the experts of dominant culture, however, is the mention that the criteria used by the appointed cultural elites are self selected by them. This research disagrees and argues that quality is not an inherent characteristic of art, but a humanly created, selected, and interpreted meritocratic category of distinction. Its meanings and values are generated through social relations and are used to disguise social difference for cultural difference. The wealth of different art production is hierarchically positioned in a class system along axes of gender, age, race, sexuality and ethnicity and legitimized according to a specific 'brow dichotomy': high-low, pure-vulgar in society. Dominant culture establishes a hierarchy of 'preferred culture' and sanctions it in institutional legitimacy over other forms of knowledge.

Conservative interests use the differences they identify to intluence and make the people' more similar, better, and more homogeneous. Some of the ways difference is circulated and is conceptualized are to define, categorize and highlight social differences with distinctions of cultural difference in order to disguise their socially generated manufacture. Subordinated people are named and positioned by their responsiveness to and differences from the self serving standards and norms nominated by the dominant culture. The people of everyday cultures are represented as having no identity that they themselves bring to the relationship. The culture of the selective tradition, a society's 'preferred culture' is portrayed as a product of a centrally mobile or culturally dominant group. It is a product of the good', of high 'quality' people, and is associated with a necessarily patriarchal democratic society. Patriarchal elitism is conceived in the concept that the right sort of elite can lead 'the people' in the right direction and to the appropriate way of life. Elitism can improve one's cultural taste and aesthetic sensibilities, enrich one's life, and enhance one's understanding of social experience.

From a conservative perspective, culture is viewed as a social universal. People strive to transcend the 'here and now' in order to distance themselves from particular places in society. Distance separates social groups along cultural lines associated with distinctions of taste. "Distance is a key marker of difference between high culture and low culture, between the 
meanings, practices and pleasures characteristic of empowered and disempowered social formations" (Fiske, 1991b, p. 154). The centrally mobile and elite attempt to spread its form of consciousness, its way of life and cultural distance throughout society, and guard itself against the challenges, resistance, and changes generated from 'below'. Distance separates people, draws distinctions and establishes borders. These borders define particular groups of people as other and outsider and designate a place of social differences disguised as cultural difference.

in Distinction; A Social Critique of Taste Bourdieu (1980) asserts that art is not a self sufficient entity. He explicitly argues against the notion of 'raditional' philosophical aesthetics. He raises serious questions about Kantian Idealism, the formation of a universal essence or category and the idea that there are such things as absolute standards of beauty that transcend social and historical difference. He clearly states that he believes that standards of taste do exist. What he empirically demonstrates is how they exist, and circulate very powerfully in society-that they misrepresent what they claim to represent. In other words, the aesthetic doesn't exist on the terms that it proposes it exists. The function of taste is to produce distinctions, a 'brow dichotomy'. It is produced on the inside and the outside of one's micro and macro environment, in the space of the social order. Taste is both "structure" and "structuring" (Bourdieu, 1980, p. 170). It is structured as a determined effect of the overall micro and macro environmental structures of capitalistic society. But, it also works actively to produce the structures that produce it. Hence, people have the potential to change the structuring mechanism through certain kinds of "actions" and antagonistic practices, i.e. tensions, resistance, and opposition. Taste is simultaneously the product of the social structures in society and the socially interested agency of people within the social structures.

In comparison to a dominant cultural interpretation of cultural practices, socio-cultural theories of the everyday recognize differences as 'conflict of social interests' and not necessarily as differences of 'quality', l.e., good-bad, right-wrong, true-false. Socio-cultural theoretical arguments are positioned to see' the conflicts of interest that pertain to a "designation of difference". Dominant culture must continually struggle to coopt the objects, once considered only relics of history, and define a place for them in the avant garde. Aesthetic discourses through the macro environmental organizations and policies, e.g. galleries, museums, and the popular periodical press, must constantly find new ways to regulate, inform the public and build awareness of a different aesthetic, and a 'newly discovered' wealth of 'otherness'. 'Distinctions of taste' are defined by the "meanings [that] circulate in multiple forms, in multiple sites and [that] are active in all modes of social experience" (Fiske, 1992, p. 17). However, difference is part of nature, and nature is full of diversity. Therefore, it is imperattve for people to erase and blur "the designation of difference" and seek, instead, ways to build respect for mutual and shared understanding of diversity. But, if this is to occur, active participation is required, not just reflection and/or contemplation.

Working Papers in Art Education 1992 


\section{Conclusion}

The struggle over the significance of the meanings and values associated with the practices of self taught vs. institutionally trained artists affects and influences real lives. It is a struggle over an accepted "official" and an opposed "unofficial" form of knowledge. The struggle is more complex than a reductive view that sees only a division between a formalistic conservative position (official art world) and an everyday alternative socio-cultural contextual view point (non-official). And while the division is real, there are many and varying views that fill the gap that reinforces and contests the "brow dichotomy". Allegiances create multiple lines of distinctions. But the overwhelming emphasis is still on the lines drawn outward from a center position, that locate individuals and collective groups on the margin. They designate a location for 'the other' on the social terrain as a particular kind of "maker". The knowledge chosen to be circulated and distributed is not neutral, but is intertwined in a fabric of social relations and cultural politics. In art education, aesthetic discourse links classroom educational experiences with the social circulation of the meanings, values and pleasures associated with particular accepted practices. While some practices are considered legitimate for study, others are passed off as not valuable, less valuable and insignificant, l.e. the practices of self taught and/or vernacular artists.

It is important to listen and record what the makers have to say about their oral life histories because what is written about "them" is very different from what they have to say about their own actual cultural practices. Research needs to record the voice of the maker and investigate in the maker's home environment, the specificlty, local variation and texture of particular discursive and non-discursive practices. The makers' views have not been adequately recorded, analyzed and culturally interpreted with respect to how makers "make do" desplte their economic, social and political designation of difference (de Certeau, 1984). It needs to become acknowledged and accepted that people are culturally productive regardless of their material existence, using the materials available around them. How are makers culturally productive (visual) in their home environment? What are the ways makers, make do-collecting, reprocessing and transforming materials in their own social space, using unwanted, discarded and unused products found in their immediate micro environment? How are cultural practices formed and how do past experiences affect and influence the formation of self identity, social identlty and social relations?

To better understand and comprehend the extensive nature of these questions, it is necessary to examine how certain forms of cultural practices and their related meanings and values circulate in and between social structures, between the micro and macro environment, particularly with regard to socially interested agency and culture, over conflict of interests, and across erected lines of official art and non-official art "making". Cultural practices are mutually informed by: 1) how economic resources are 
distributed (material), 2) how the meanings and values associated with them circulate (semiotic) in the 'art world', in educational institutions and in the makers' home environment, and 3) how the specificity, local variation and textuality of the micro environment contribute to the formation of the makers' cultural self and social identity. The gap that has formed between views of what counts as legitimate or official and unofficial art knowledge is a result of the preceding problem. It is visible in society in the actions, policies and organizations of the macro environment. But it is also visible in the cultural practices of makers. Therefore, aesthetic discourses and the story events the makers tell about themselves over the distinctions of taste and a designation of difference need to be socially, historically and contextually situated within the economic, political and cultural spheres of society.

\section{References}

Appadurai, A. (1986). The Social Life of Things: Commodities in Cultural Perspective. Cambridge: Cambridge University Press.

Apple, M. (1979). Ideology and Curriculum. London: Routledge and Kegan Paul.

Apple, M. (1982). Education and Power. Boston, London and Henley: Ark Paperbacks.

Archer, M. (1988). Culture and Agency: The Place of Culture in Social Theory. Cambridge: Cambridge University Press.

Ardery, J. (1991). The Designation of Difference. New Art Examiner, 9, 2932.

Bahktin, M. (1981). The Dialogic Imagination. C. Emerson \& M. Holiquist, Trans. Austin: University of Texas Press.

Bahktin, M. (1984). Rabelais and His World. (H. Iswolsky, Trans.).

Barken, M. (1955). A Foundation tor Art Education. New York: Ronald.

Barthes, R. (1973). Mythologies, translated by Jonathan Cape Ltd. New York: The Noonday Press, Farrar, Straus, and Giroux.

Bauman, Z. (1974). Culture as Praxis. London: Routledge and Kegan.

Benjamin, W. (1968). Illuminations: Essays and Reflections. In Hannah Andt (Ed.), New York: Pantheon Books.

Berger, J. (1972). Ways of Seeing. London: British Broadcasting Corporation. 
Berger, P., \& Lackmann, T. (1966). The Social Construction of Reality: A Treatise in the Sociology of Knowledge. New York: Dell Publishing Group, Inc.

Bersson, R. (1983). For Cultural Democracy: A Critique of Elitism in Art Education. The Bulletin of the Caucus on Social Theory and Art Education, 3, pp. 25-32.

Beyer, L, \& Apple, M.W., (Eds.). (1988). The Curriculum: Problems, Politics and Possibilities. Albany, N.Y.: The State Unlversity of New York Press.

Beyer, $L$ (1984). "The Arts, School Practice, and Cultural Transformation". The Bulletin of the Caucus on Social Theory and Art Education, 4, pp. 1-13.

Bourdieu, P. (1980). Distinction: A Social Critique of the Judgement of Taste. (R. Nice, Trans.) Cambridge: Harvard University Press.

Boyer, B. (1987). Cultural Literacy in Art: Developing Conscious Aesthetic choices in Art Education. In D. Blandy \& K.G. Congdon (Eds.), Art in a democracy (pp. 91-106). New York: Teachers College Press.

Broudy, H.S. (1972). Enlightened Cherishing. Urbana, III.: University of Illinois Press.

Cardinal, R. (1972). Outsider Art. New York: Praeger Publishers.

Carter, C.L (1992). Contemporary American Folk Art: The Balsley Collection. Milwaukee: Marquette University.

Chalmers, G. (1985). Art As A Social Study: Theory Into Practice. The Bulletin of the Caucus On Social Theory and Art Education, 5, pp. 40-50.

Congdon, K (1992). The Centrality of Women Artists' Traditional Creativity. Unpublished Paper.

Danto, A. (1981). The Transfiguration of the Commonplace. Cambridge: Cambridge University Press.

de Certeau, M. (1984). The Practice of Everyday Life. Berkeley: University of California Press.

de Certeau, M. (1986). Hetergoiogies: Discourse on the Other, (written in collaboration with Dominique Julia and Jacque Revel). Paris: U.G.E. 
Dissanayake, E. (1985). What Is Art For? United States: University of Washington Press.

Dreyfus, H.L \& Rabinow, R. (1982). Michel Foucault: Beyond Structuralism and Hermeneutics. Brighton, Sussex: The Harvard Press.

Duncum, P. (1988). Toward Foundations for a Socially Critical Art Education. The Journal of Social Theory in Art Education, (9), pp. 12-25.

Eagleton, T. (1990). The Ideology of the Aesthetic. Oxford: Basil Blackwell, Ltd.

Feldman, E.B. (1970). Engaging Art in Dialogue. In G. Pappas (Ed.), Concepts in Art and Education. London: MacMillan.

Feldman, E.B. (1971). Varieties of Visual Experience. New York: Prentice Hall.

Fiske, J. (1987). Television Culture. London: Methuen.

Fiske, J. (1989). Understanding Popular Culture. Boston: Unwin Hyman.

Fiske, J. (1990). Introduction to Communication Studies, (2nd. ed.). London: Routledge.

Fiske, J. (1991a). For Cultural Interpretation: A Study of the Homelessness. Unpublished paper.

Fiske, J. (1991b). Cultural Studies and the Culture of Everyday Life. In Grossberg, Nelson and Trelchler (Eds.), Cultural Studies: Now and in the Future. New York: Routledge.

Foucault, M. (1977). Discipline and Punishment: The Birth of the Prison. London: Allen Lane.

Foucault, M. (1980). Power/Knowledge: Selected Interviews \& Other Writings, 1972-1977. In Colin Gordon, (Ed.), New York: Panthon Books.

Freedman, K (1989). Dilemmas of Equality in Art Education: Ideologies of Individualism and Cultural Capitol, In W.G. Secada (Ed.), Equity in Education, London: Falmer Press.

Gee, J.P. (1991). The Narratization of Experience in the Oral Style. In Rewriting Lteracy: Culture and the Discourse of the Other. C. Mitchell \& K. Weiler (Eds.). New York: Bergin \& Garvey. 
Georges, R. (1969). Toward an Understanding of Storytelling Events. Journal of American Folklore, 82, 316.

Gibson, M. (1976). Approaches to Multicultural Education in the United States: Some Concepts and Assumptions. Anthropology and Education Quarterly, 74 (4), 7-18.

Giddens, A. (1979). Central Problems in Social Theory. London: Macmillan.

Gollneck, D.M., \& Chinn, P.C. (1986). Multicultural Education in a Pluralistic Society, (2nd. ed.). Columbus: Charles E. Merrill.

Gottschalk, D. (1947). Art and the Social Order. Chicago: The University of Chicago Press.

Hall, M.D. (1991). The Mythic Outsider: Hand Maiden to the Modern Muse. New Art Examiner, 9, 16-21.

Hall, S. (1981). Notes on Deconstructing "The Popular", In R. Samuel (Ed.), (1981), Peoples' History and Socialist Theory, London: Routledge \& Kegan Paul, pp. 227-240.

Hall, S. (1980). Culture Studies and the Centre: Some Problematics and Problems. In Stuart Hall, Dorothy Hobson, Andrew Lowe, and Paul Willis (Eds.), Culture, Media, Language: Working Papers in Cultural Studies, 1972-1979, London: Hutchinson.

Hamblen, K.A. (1988). Cultural Literacy Through DBAE Repertoires. Journal of Multicultural and Cross-cultural Research in Art Education, 6, pp. 88-98.

Hamblen, K.A. (1990). Beyond the Aesthetic and Cash Culture Litetracy. Studies in Art Education, 31 (4), pp. 216-225.

Hobbs, J. (1975). Art in Context. New York: Harcourt Brace Jovanovich.

Hodge, R. \& Kress, G. (1988). Social Semiotics. Ithaca, N.Y.: Cornell University Press.

Hofstadter, A. \& Kuhns, R. (1976). Immanuel Kant: Selections from "Critique of Judgement". In Philosophy of Art and Beauty: Selected Readings in Aesthetics from Plato to Heidegger, (J. H. Bernard, Trans.), Chicago: The University of Chicago Press. pp. 277-343

hooks, b. (1992). Black Looks: Race and Representation. Boston: South End Press. 
hooks, b. (1990). Yearning: Race, Gender, and Cultural Politics. Boston: South End Press.

Horwitz, E.L. (1975). Contemporary American Folk Artists. Philadelphia: J.B. Lippincott Company.

Irwin, D. (1982). Baskets and basket makers in southern Appalachia. Exton, PA: Schiffer.

Johnson, N. (1988). DBAE and CLAE. The Journal of Social Theory in Art Education, 9, pp. 45-48.

Jones, M. (1975). The Hand Made Object and Its Maker. Berkeley: University of California Press.

Jagadinski, J. (1981). Aesthetic Education Reconsidered or Please Don't Have an Aesthetic Experience! The Journal of the National Art Education Association, 34 (3), pp. 45-48.

Lanier, V. (1976). The Unseeing Eye: Critical Consciousness and the Teaching of Art. In E. W. Eisner (Ed.), The Arts, Human Development and Education, Berkeley: McCutchan. pp. 19-29.

Lefebvre, H. (1971). Everyday Life in the Modern World. London; Harper \& Row.

Levi-Strauss, C. (1969). The Raw and the Cooked. London: Cape.

Levine, L (1988). Highbrow/Lowbrow: The Emergence of Cultural Hierarchy in America. Cambridge: Harvard University Press.

Lippard, L.R. (1991). Mixed Blessings: New Art in a Multicultural America. New York: Panteon Books.

Manley, R. (1992). Hermon Finney. Raw Vision, 5, 20-25.

Manley, R. (1991). Separating the Folk from their Art. New Art Examiner, 9, 25-28.

McFee, J.K. (1988). Cultural Dimensions in the Teaching of Art. In F.H. Farley \& R.W. Neperud (Eds.), The Foundation of Aesthetics, Art and Art Education, New York: Praeger.

Muscoda Village Planning Commission. (1977). Muscoda Wisconsin Comprehensive Planning Program. (Prepared in cooperation with the Wisconsin Department of Local Affairs and Development, SWWRPC-77-PR-24). Washington, D.C. 
Nadaner, D. (1985). Critique and Intervention: Implications of Social Theory for Art Education. Studies in Art Education, 26, pp. 20-26.

Neperud, R. (1988). Conceptions of Art in the Service of Art and Aesthetic Education: A Critical View. Arts and Learning Research, 6, 95-102.

Rosenblum, P. (1981). The Popular Culture and An Education. The Journal of the National Art Education Association, 34 (1), pp. 8-11.

Rumford, B. (1980). Uncommon art of the common people: A review of trends in the collecting and exhibiting of American folk art. In I. M. Quinby \& S. T. Swank (Eds.), Perspectives in American folk art. New York: W. W. Norton.

Sherzer, J. (1983). Kuna Ways of Speaking: An Ethnographic Perspective. Austin: University of Texas Press.

Sleeter, C. \& Grant C. (1987). An Analysis of Multicultural Art Education in the United States. INSESA News, 1, 14-15.

Smlth, R. (1967). An exemplar approach to aesthetic education. (Bureau of Educational Research, Project \# 6-3-6-06127-1609). Washington: U. S. Office of Education \& Department of Health, Education \& Welfare.

Smith, R. (1986). Excellence in art education: Ideas and initiatives. Reston, VA: NAEA.

Sola M. \& Bennett, A. (1991). The Struggle for Voice: Narrative, Literacy and Consciousness in an East Harlem School. In Rewriting literacy: Culture and the discourse of the other. C. Mitchell \& K. Weiler (Eds.). New York: Bergin \& Garvey.

Staff. (1985, February 7). Steel Dinosaur Protects Muscoda's South Side. The Progressive, p. 1.

Staff. (1985, March 21). He made "Tin Man" from Wizard of Oz. Boscobel Dial, p. 1.

Staff. (1986, March 31). Mechanical Man. Telegraph Herald, p. 25.

Stallybrass, P., White, A. (1986). The Politics and Poetics of Transgression. New York: Cornell University Press.

Stokrocki, M. (1988). Understanding Popular Culture: The Uses and Abuses of Fashion Advertising. The Bulletin of the Caucus on Social Theory and Art Education, 8, pp. 69-77.

Working Papers in Art Education 1992 
Tannen, D. (1984). Coherence in Spoken and Written Discourse. Norwood, NJ: Ablex.

Thompson, E.P. (1962). The Long Revolution. New Left Review, 9, pp. 24-34.

Vattimo, G. (1988). The End of Modernity, (J.R. Snyder, Trans.). Baltimore: The Johns Hopkins University Press.

Vlach, J. (1991). A call for a new approach to folk art: The wrong stuff. New Art Examiner, 9, 22-24.

Volosinov, V.N. (1973). Marxism and the Philosophy of Language, translated by Ladislav Matejka and I. R. Titunik. Cambridge: Harvard University Press.

Wasson, R., Stuhr, P., \& Petrovich-Mwaniki, L (1990). Teaching Art in the Multicultural Classroom: Six Position Statements. Studies in Art Education, 31 (4), pp. 234-246.

Williams, R. (1977). Marxism and Literature. Oxford: Oxford University Press.

Williams, R. (1979). Politics and Letters: Interviews With the "New Left Review". London: New Left Books.

Williams, R. (1981). Culture. Glasgow: Fontana and Collins.

Williams, R. (1983). Keywords, (2nd. ed). Glasgow: Fontana.

Willis, Paul (1990). Common Culture: Symbolic Work at Play in the Everyday Cultures of the Young. Boulder: Westview Press.

Wolff, J. (1983). Aesthetics and the Sociology of Art. London: George Allen \& Unwin.

Wolff, J. (1981). The Social Production of Art. Hong Kong: New York University Press.

Zurmuehlen, M. (1990). Studio Art: Praxis, Symbol, Presence. Reston, Va.: NAEA. 